\title{
Correction: Phenotypic and genomic analyses of bacteriophages targeting environmental and clinical CS3-expressing enterotoxigenic Escherichia coli (ETEC) strains
}

Sajib Chakraborty, Astrid von Mentzer, Yasmin Ara Begum, Mehnaz Manzur, Mahmudul Hasan, Amar N. Ghosh, M. Anwar Hossain, Andrew Camilli, Firdausi Qadri

The second author's initials appear incorrectly in the citation. The correct citation is: Chakraborty S, von Mentzer A, Begum YA, Manzur M, Hasan M, Ghosh AN, et al. (2018) Phenotypic and genomic analyses of bacteriophages targeting environmental and clinical CS3-expressing enterotoxigenic Escherichia coli (ETEC) strains. PLoS ONE 13(12): e0209357. https://doi.org/ 10.1371/journal.pone.0209357

\section{Reference}

1. Chakraborty S, Mentzer Av, Begum YA, Manzur M, Hasan M, Ghosh AN, et al. (2018) Phenotypic and genomic analyses of bacteriophages targeting environmental and clinical CS3-expressing enterotoxigenic Escherichia coli (ETEC) strains. PLoS ONE 13(12): e0209357. https://doi.org/10.1371/journal. pone.0209357 PMID: 30571788

G

\section{OPEN ACCESS}

Citation: Chakraborty S, von Mentzer A, Begum YA, Manzur M, Hasan M, Ghosh AN, et al. (2019) Correction: Phenotypic and genomic analyses of bacteriophages targeting environmental and clinical CS3-expressing enterotoxigenic Escherichia coli (ETEC) strains. PLoS ONE 14(3): e0213612. https://doi.org/10.1371/journal.pone.0213612

Published: March 5, 2019

Copyright: $\odot 2019$ Chakraborty et al. This is an open access article distributed under the terms of the Creative Commons Attribution License, which permits unrestricted use, distribution, and reproduction in any medium, provided the original author and source are credited. 